\title{
¿Cómo se inscribe el sufrimiento en el cuerpo? \\ Cuerpo, mística y sufrimiento en la Nueva Granada a partir de las historias de vida de Jerónima Nava y Saavedra y Gertrudis de Santa Inés ${ }^{1}$
}

\author{
Juan Pablo Aranguren Romero \\ Facultad Latinoamericana de Ciencias Sociales (Flacso), Argentina \\ jesuispablo@hotmail.com
}

\begin{abstract}
Resumen
En este artículo se abordan las formas en que el sufrimiento se inscribe en el cuerpo, analizando los correlatos de tales padecimientos a partir de las narraciones de la monja Jerónima Nava y a través de la historia de vida de Gertrudis de Santa Inés, escrita por su confesor. Para tal fin se avanza en la comprensión de los ordenamientos sociales en la Nueva Granada en el siglo XVII, así como en el entendimiento de las dinámicas de la vida conventual en la época. Se parte de una concepción amplia de lo corporal que se extiende a una noción de sufrimiento entendible junto con la noción de goce; las experiencias místicas, así, serán abordables desde estas nociones, en aras de establecer qué dicen a propósito de las prácticas subjetivas y de un discurso ejemplificante y ordenador que rodea y enmarca a las mujeres en este contexto.
\end{abstract}

Palabras clave: cuerpo, sufrimiento, Nueva Granada, monjas, mística, siglo XVII, siglo XVIII, psicoanálisis.

\begin{abstract}
This article examines the forms how suffering is inscribed in the body, by analyzing the narrations by the nun Jerónima Nava and the biography of Gertrudis de Santa Inés, written by her confessor. It also deals with social arrangements and the dynamics of conventual life in the 17th-century New Granada. The starting point is a wide concept of "the corporal" which is

\footnotetext{
${ }^{1}$ Esta investigación fue realizada con el apoyo del Instituto Colombiano de Antropología e Historia y presentada como trabajo de grado para obtener el título de historiador en la Pontificia Universidad Javeriana, donde obtuvo el reconocimiento de tesis laureada.
} 


\section{FRONTERAS}

de la fistoria

extended to a notion of suffering understandable together with the notion of enjoyment. Mystical experiences can be approachable from these notions in order to understand what they tell about subjective practices and exemplifying and ordering discourses about women in this context.

Key words: Body, suffering, New Granada, nuns, mystic, 17th century, 18th century, sychoanalysis.

\section{Introducción}

Avanzar en una pregunta por las formas en las que el sufrimiento se inscribe en el cuerpo en el contexto neogranadino a finales del siglo XVII y comienzos del XVIII supone recorrer un camino en el que se entrecruzan las vertientes de la experiencia personal y del entramado social. En una y otra confluye tanto la institución eclesial, facilitadora del ordenamiento y el control social, como las prácticas de los fieles guiados por estos parámetros eclesiales. En todo caso el sufrimiento corporal será un punto esencial en ese proceso de incorporación de la normatividad social y cuanto marco de posibilidad de interlocución con Dios.

Un proceso tal no será ajeno a las dinámicas sociales de la Nueva Granada, porque justamente es producto de dicho contexto. Así, la lectura de las formas en las cuales se inscribe el sufrimiento en el cuerpo en el marco de las experiencias místicas, supondrá tener presente que las dinámicas sociales, más que atravesar los procesos de la vida espiritual y religiosa, están esencial y plenamente sostenidas y movilizadas por ellos. El avance en la comprensión de las lógicas del relacionamiento social, de las prácticas políticas y económicas y, por lo tanto, de la vida cotidiana, demanda de esta manera un acercamiento al entramado de la vida religiosa como punto sustancial de la sociedad, la política, la economía y la cotidianidad. Esto significa que la lectura de la vida cotidiana y de los intersticios de la política y la economía neogranadinas supone trazar un recorrido por los avatares de una parte de esa vida religiosa — en este caso el cuerpo- a través del cual se podrá reconocer que las lógicas de una sociedad tal están ampliamente sostenidas sobre las concepciones del mundo y de la realidad espiritual.

El análisis acerca de cómo se inscribe el sufrimiento en el cuerpo, privilegia en este trabajo dos escritos de singular relevancia a través de los cuales se puede acceder tanto a la comprensión de las formas en las que este tipo de producción escritural se materializa en modelos ejemplificantes de vida, como a los visos de 
subjetividad que emergen en estos textos. Se trata de la narraciones de experiencias místicas de Jerónima Nava y Saavedra y de Gertrudis de Santa Inés (contemporáneas: Jerónima vivió entre 1669 y 1727, y Gertrudis, entre 1668 y 1731).

La vida de Jerónima fue transcrita y publicada en 1994 por Ángela Robledo, quien constató que ésta consiste en una recopilación de una serie de "papeles" escritos por esta monja clarisa de velo negro en el Convento de Santa Clara en Santafé, por mandato de su confesor Juan de Olmos y Zapiaín, quien los reuniría agregando aparentemente sólo una introducción al texto o "elogio de la autora" como le denomina Robledo ${ }^{2}$. En el caso de la vida de sor María Gertrudis Teresa de Santa Inés, religiosa dominica, también de velo negro pero en el convento de Santa Inés en Santa Fe, se trata de un texto elaborado por su confesor Pedro Andrés Calvo de la Riba, quien cita algunos apartes de la confesión que ha solicitado a la monja.

Como se podrá notar, la escogencia de estos dos textos responde a las cercanías $\mathrm{y}$ coincidencias en el tiempo en el que vivieron las dos monjas. De igual manera, corresponde al hecho de que la producción escritural de una y otra privilegia lugares de enunciación significativos para el análisis y la comparación. En el texto de Jerónima, la narración de sus experiencias de vida mística - de sus encuentros con la teofanía - dan cuenta de una narración que en apariencia no ha sido completamente atravesada por la censura y la interpretación eclesial, como sí será evidente en el texto acerca de la vida de

\footnotetext{
${ }^{2}$ El velo negro define una estratificación social entre las monjas, materializada en la dote exigida a cada una de ellas. Según Pilar Zuleta, desde la segunda mitad del siglo XVII hasta el siglo XVIII para las religiosas de velo negro la dote era de 1.000 a 2.000 pesos, y para las de velo blanco entre 400 y 600 pesos En ambos casos esta dote era menor que la exigida para un matrimonio (6.000 pesos en los más modestos y hasta 34.000 en los de una familia de la élite neogranadina). El velo, en cuanto recubrimiento corporal, se constituye en un signo particular de distinción que posibilita una diferenciación (el velo negro en muchos casos fue exclusivo para mujeres españolas o de origen español, pero en todo caso con un linaje demostrable) y establece un vínculo identificatorio (será diciente de la sujeción de la monja al convento). Con el velo se recubre el cuerpo de un orden y un código particulares, a través de los cuales se incorporan la renuncia al mundo, el ordenamiento y la estratificación social. Las vestimentas con las que es recubierto, adornado y ceñido hacen que el cuerpo sea a su vez portador y emisor de signos: el velo en este caso no sólo se constituye en una forma de expresar una diferenciación social, también es la manera de hacer visible algo de esa condición moral interior que se presupone igualmente distinguida (Zuleta 426-27).
} 


\section{FRONTERAS}

de la fistoria

Gertrudis $^{3}$. Esta diferencia remite esencialmente al hecho de que la vida de Gertrudis es un texto impreso con las autorizaciones eclesiales y licencias requeridas para ello. Es, además, un texto que se tasó "a seis maravedís cada pliego", por lo que se hace evidente su divulgación. En el caso de la vida de Jerónima se trata de un texto "manuscrito" que, según los análisis de Robledo, el original (ubicado en el Museo Nacional) sólo cuenta con una copia transcrita que reposa en el Convento de Santa Clara. El texto de la vida de Gertrudis contendría así, menos el puño y letra de la monja y más las interpretaciones y composiciones de su confesor, aunque con abundantes citas que remiten a "papeles" con los mismos rasgos de autoría que los del texto acerca de la vida de Jerónima.

Sin embargo, no es posible suponer acá que en el ejercicio escritural de Jerónima no interviene el ordenamiento y la censura eclesial sólo por el hecho de constatar en el manuscrito la letra de la monja. En Jerónima, al igual que en Gertrudis, operarán estas restricciones desde el ejercicio mismo de la producción escritural realizado por mandato del confesor y, por lo tanto, como un ejercicio de dar cuenta de las experiencias y sensaciones vividas en el marco del encuentro con Dios. Así, los textos si bien pueden ser considerados como un ejercicio de reflexión personal que da cuenta de una subjetividad implicada en su construcción, son en todo caso producidos en el marco de una serie de ordenamientos eclesiales — masculinos - que si bien los hace posibles, también les da un campo "restringido" de posibilidad.

Este trabajo persigue la interpretación y comprensión tanto de los ordenamientos sociales que rigen la vida de las mujeres - y específicamente la vida conventual-, como de ese sujeto femenino, emergente a través de la escritura y en virtud de las posibilidades que le ofrecen tales ordenamientos sociales. El recorrido en uno y otro caso tendrá como lugar privilegiado el cuerpo: inscrito, signado y mortificado por las marcas de tales ordenamientos; ofrecimiento esencial para el encuentro con la teofanía y sacrificio necesario para la salvaguardia de la moral social. Este cuerpo mortificado, hecho texto

\footnotetext{
${ }^{3}$ Difiero de Ángela Inés Robledo en considerar el texto de Jerónima Nava y Saavedra como una autobiografía, toda vez que éste es más una narración de algunas experiencias de vida de la monja y en virtud de que, como bien señala Ferrús, "entre vida y autobiografía existen diversos elementos de continuidad pero, ante todo, notables diferencias". Estas diferencias tienen que ver esencialmente con el ejercicio de conciencia de sí, favorecido por la reflexión que encamina las vidas, pero sin los matices propios de un texto acerca de sí presente en la autobiografia (Robledo). Para Ferrús, entre una y otra estará el paso del "yo-cuerpo" al "yo-sujeto" (10).
} 
para el Otro, pondrá de manifiesto que esta escritura de sufrimiento, esta letra con sangre, en cuanto experiencia escritural y experiencia corporal, es una experiencia subjetiva.

La experiencia, como intentaremos mostrar aquí, será la de un sujeto que justamente tiene conciencia de su cuerpo para ofrecerlo en sacrificio y en la letra; una experiencia de sujeción a una "nueva normatividad", un sujeto que debe emerger para entrar en un ordenamiento que clamará su borramiento. Desde esta hipótesis, los análisis de las historias de vida elegidas privilegian la lectura de las descripciones de las experiencias místicas de las monjas a través de los planteamientos psicoanalíticos lacanianos en torno al cuerpo y al sufrimiento. Lejos de cualquier pretensión de hacer de este un trabajo desde la psicohistoria, en esta investigación consideramos pertinente favorecer una interlocución entre el psicoanálisis, la historia y la antropología, en la que si bien se reconoce a cada disciplina su especificidad, no se desconocen sus relaciones de vecindad y sus posibilidades de traspasar los muros y fronteras que en muchos casos las dividen ${ }^{4}$. Situado en un contexto específico tanto de producción como en relación al tema de análisis, este trabajo destaca, a la vez, la historicidad del cuerpo y del sufrimiento y la posibilidad de hacerlo a través del sujeto que dice "tengo un cuerpo". En virtud de ello este trabajo reclama para el cuerpo una subjetividad susceptible de ser interpretada y releída en virtud de los aportes de los planteamientos psicoanalíticos y en razón de sus lugares de producción.

El lugar en el que sitúa la perspectiva psicoanalítica al cuerpo toma distancia frente a aquellos formalismos que pretenden hacer del sujeto un dato perfectamente calculable y previsible; este lugar habla de un cuerpo que se construye en la operancia y la conjunción de los órdenes real, simbólico e imaginario. Es un cuerpo construido; constituido al ser atravesado por el lenguaje y, en esa medida, proveedor de una imagen que representa al sujeto. El cuerpo es, pues, intervenido por lo simbólico; antes del lenguaje sólo hay "carne insignificante" (Bicecci 276), no hay cuerpo antes del lenguaje. Al ser invadida por el decir, la carne se hace cuerpo tomando a su vez consistencia imaginaria y dando unidad y cohesión a la fragmentación que antecede al reconocimiento corporal. Se entiende así que lo corpóreo se ubica más allá de una mera dimensión física o biológica, es más que un organismo; el cuerpo se inaugura al

\footnotetext{
${ }^{4}$ Sobre los puntos de encuentro entre historia y psicoanálisis es importante considerar las reflexiones de Certeau (Historia). En el caso colombiano, Bernardo Tovar ha insistido en la necesidad de promover estas cercanías.
} 


\section{FRONTERAS}

de la historia

ser atravesado por el lenguaje y al acceder al reconocimiento de una imagen que le provee consistencia. Esta imagen cohesionadora es introducida por el significante, por el lenguaje: el significante introduce lo uno en el organismo (Soler).

En esa medida se puede comprender que en el cuerpo siempre hay algo que permanece "inabordable, insondable y misterioso" (Bicecci 277) y que se trata de eso real del cuerpo huidizo a toda captura discursiva. Lo que es susceptible de captura - en realidad es apenas bordeable - es el cuerpo constituido sólo cuando ha sido atravesado por el significante, organizado a partir de lo simbólico, es decir, en el campo del Otro. El cuerpo se constituye así a partir de un organismo vivo, un significante que lo atraviesa y una imagen que le da consistencia.

\section{Y el Verbo se hizo carne (o de la incorporación de los discursos de ordenamiento)}

Las dinámicas sociales de finales del siglo XVII en la Nueva Granada incluyen el despliegue de una serie de ordenamientos discursivos que son fruto del proceso de constitución del poder colonial y que apuntan a la conservación de la moral pública y a la salvaguarda de los valores cristianos. La implementación de estas normatividades no se consolidará de manera exitosa, ya que, entre la formulación de las normas y la práctica de éstas habrá un amplio distanciamiento. Los ejercicios de control y vigilancia contrastarán así con el amplio volumen de procesos judiciales emprendidos justamente contra aquellos que no dan cumplimiento a la ley por medio de sus acciones y comportamientos.

El interés por desarrollar dispositivos que favorezcan el control de la vida social colonial se abre paso como una necesidad importante para la implementación del proyecto de dominación española. Para el siglo XVII varios autores insisten en que en la Nueva Granada y en general en los virreinatos se había solventado esa difícil etapa de evangelización que había ocupado a los colonizadores a mediados del siglo XVI, caracterizada por la confusión y la dificultad de administrar tierras y grupos humanos, con lo cual se consolidó una etapa de "estabilización virreinal".

\footnotetext{
${ }^{5}$ Al respecto, véanse Borja ("Santidad” 18-19); Jaramillo; Moraña; Villari.
} 
Sin embargo, es fundamental tener presente una constante en el proceso de implementación del orden español en las indias con cierta vigencia a mediados del siglo XVII: aun cuando se despliega una multiforme estrategia de vigilancia, muchos serán los comportamientos que infringirán esta normatividad poniendo de presente una incorporación parcial del ordenamiento social promulgado desde los ámbitos eclesiales. El interés y la necesidad de implementación de un ordenamiento social acorde con las necesidades colonizadoras harán de la vigilancia y el control una práctica cotidiana.

Nada más característico que las rondas nocturnas de alcaldes y alguaciles que buscaban penetrar en la intimidad de zaguanes y de alcobas antes que prevenir desórdenes callejeros (Colmenares 6).

Para 1668, por ejemplo, los oidores Leyva y Campuzano ordenaban la realización de rondas nocturnas a fin de sorprender a aquellas personas que atentaban con sus comportamientos contra la moral pública y contra los valores cristianos. En el resultado de uno de tantos recorridos nocturnos serán "cogidos infraganti, varios casados" (AGN, $P 2$, ff. 1045-1049) ${ }^{6}$.

Sin duda, una parte importante de eso que atenta contra la moral pública y que por lo tanto deberá ser objeto de control es la vida sexual. El desenfreno de las pasiones, los encuentros amorosos ilícitos o las formas de goce sexual contra natura, serán objeto de vigilancia y control por parte de la Iglesia. En virtud de ello también será evidencia de unas prácticas cotidianas frente a la sexualidad: antes de la ley estará el crimen (Vega).

La vigilancia como una forma de procurar la defensa de la fe y la moral no será competencia únicamente de los oidores, curas y alguaciles, sino también de todos los vecinos, que deben rechazar y denunciar estos actos ilícitos e inmorales.

Este rechazo pondrá de manifiesto la incorporación del discurso de ordenamiento moral entre muchas personas, y será evidencia, además, de las extensiones de la estrategia de control. Así, defender la moral pública será paulatinamente una competencia de toda la sociedad, toda vez que cuando se

\footnotetext{
${ }^{6}$ En ese sentido son interesantes el juicio seguido a Juan Rodríguez Callejas, a quien se le sorprendió en flagrancia con una mujer casada "faltando al sexto mandamiento" (AGN, JC 10, ff. 832-835) y el que se le siguió a Felipe Álvarez "por haberse traído de Mérida, una amante" (AGN, JC 4, ff. 921-927).
} 


\section{FRONTERAS}

de la historia

atente contra ella se atentará justamente contra la moral pública (Borja, "Tendencias") 7 .

En el marco de una vigilancia tal y de una necesidad eclesial de autoridad sobre la sexualidad y la vida en general de las personas, el control sobre la vida femenina será un punto fundamental en la consecución de estos fines. Dicho control responderá a una tradición europea que sitúa a las mujeres en un lugar donde los constreñimientos y las formas de ordenamiento sobre sus cuerpos son indispensables para la prevención de los pecados. Ya sea a través de la educación, la familia, el esposo, la casa o el convento, las mujeres serán objeto de vigilancia constante por parte de la Iglesia ${ }^{8}$. Para efectos de este trabajo nos adentraremos en la vida conventual de las mujeres y en la tradición en la que se enmarca, intentando bordear el lugar de producción escritural de dos monjas a finales del siglo XVII y comienzos del XVIII en Santa Fe. Partiremos, en todo caso, de la escasez de fuentes relacionadas con el papel de las mujeres en la sociedad que tengan su origen en ellas mismas, teniendo presente, por lo tanto, que dicha producción estará atravesada por hombres, particularmente pertenecientes al ámbito eclesial ${ }^{9}$.

\section{El lugar de lo femenino}

La tradición medieval da cuenta, particularmente desde el siglo XII, de un nuevo y creciente interés eclesial por el comportamiento de las mujeres. Esta

\footnotetext{
${ }^{7}$ Varias de las causas criminales proferidas contra parejas adúlteras o en amancebamiento resaltan como delito el vivir en forma "escandalosa" o "atentando contra la moralidad pública". Escandalizar se refiere a "causar escándalo, dando motivo para que otros discurran o piensen mal de las acciones del próximo" (Diccionario 2: 552).

${ }^{8}$ Toda vez que en este artículo no se pretende profundizar en las formas de contravención de la moral sexual en el siglo XVII en el Nuevo Reino de Granada, sólo se han planteado algunos ejemplos que sirven para enmarcar los ordenamientos que recaen sobre las mujeres en este contexto. En relación con el tema, véase Aranguren.

${ }^{9}$ Compartimos en parte la idea de Asunción Lavrin según la cual "los escritos de las religiosas que tenemos a nuestra disposición nos dicen mucho sobre sus experiencias en materia de religión, pero no son buenos índices para juzgar sus experiencias en la vida secular" (35). Pero será un objetivo de este trabajo situar esa experiencia religiosa en estrecha relación con lo secular.
} 
preocupación formaba parte del espíritu de renovación moral proclamado por la iglesia con la reforma gregoriana ${ }^{10}$.

Para controlar a sus mujeres, los esposos no muestran oposición a la intervención de los sacerdotes en la pareja. De esta forma, los esposos están protegidos contra el arsenal misterioso con el que cuentan las mujeres: "las damas elaboran entre ellas sospechosas mixturas, comenzando por los afeites, los ungüentos, las ceras depilatorias que utilizan, disfrazando su apariencia corporal para presentarse, engañosas a los hombres. Putas vuélvense vírgenes $y$, feas y arrugadas, bellas" (cursivas añadidas; cit. en Duby, Damas 16).

En esa medida, los clérigos estaban de acuerdo en la necesidad de impedir a la mujer hacer el mal. De ese modo, el matrimonio se convirtió en la opción ideal para encasillar a la mujer; "aquella que espera todo de su señor, que le ama, pero que, sobre todo, le teme" (Duby, Leonor 55). En el marco de una marginación de la mujer y de la misoginia donde la mujer no sólo es susceptible del mal, sino que además es portadora del honor de los hombres, nacerá un imperativo de tutela y control que llevará a justificar muchas violencias contra ellas (Rodríguez 244).

El control de las esposas pasa especialmente por el control del cuerpo, desconfiando constantemente de sus exigencias ${ }^{11}$. El cuerpo de la mujer deberá ser objeto de control en virtud de su naturaleza inconstante y "del mal gobierno que le da una razón incompleta propia de las mujeres" (Klapisch). Ese cuerpo exigirá del esposo una prudente satisfacción de los apetitos carnales, exigencia que contrastará con los amancebamientos exacerbados en donde el marido termina "abandonado al vértigo de los sentidos". Por otro, supone el control de sus tiempos y movimientos:

\footnotetext{
${ }^{10} \mathrm{Sin}$ embargo, es preciso tener presente que hacia el siglo XI, "el esquema tripartito que domina las concepciones de la sociedad cristiana no asigna ningún puesto específico a las mujeres. Jerarquiza 'órdenes' o 'condiciones' — caballeros, clérigos, campesinos-, pero esta pirámide en la cual los que rezan, los que combaten o administran justicia compiten por la conquista del puesto más elevado, no contempla una 'condición femenina'" (Klapisch).

${ }^{11}$ Los hombres eran propensos a ver "en los pecados de las mujeres una naturaleza corporal o sexual considerándolos como si provinieran del interior de su cuerpo, mientras que se representaba a los hombres pecadores como seducidos desde fuera - frecuentemente tentados de hecho por la corporeidad que la mujer les ofrecía" (Walter 178).
} 


\section{FRONTERAS}

de la fistoria

Sus salidas al exterior deben limitarse a recorridos muy controlados: iglesia, lavadero, horno público o fuente, lugares que cambian según la condición social, pero señalados con precisión. Lugares también que despiertan curiosidad y angustia en los hombres; hasta tal punto que tienen la impresión de que las palabras que se dicen escapan a su vigilancia. (Klapisch 317 ).

Tales imperativos no impedirán, en todo caso, la emergencia de mujeres como Hildegarda o las beguinas, quienes pondrán de manifiesto la trascendencia de la feminidad en el ejercicio espiritual y empezarán a dar cuenta de ello en sus escritos $^{12}$.

Una parte importante de esta tradición medieval se pondrá en circulación en las dinámicas sociales en las que las mujeres se inscribirán en el Nuevo Reino de Granada. Para finales del siglo XVII, aunque el papel de la mujer es mucho más activo en estas dinámicas, la sociedad masculina privilegiará para ellas, junto al matrimonio, la vida conventual. La reclusión será así un ejercicio necesario para el control de la mujer, pero también uno de los escenarios donde ésta gana de cierta manera 'autonomía'.

En todo caso, siempre habrá — respondiendo también a la tradición medieval— una actitud de cautela y recelo por parte de la autoridad eclesiástica, ante el despliegue de dicha "autonomía". Las experiencias místicas de las mujeres que emergerán en estos escenarios serán vistas con preocupación: "No porque estas revelanderas impugnaran el dogma o atacaran la jerarquía [...], sino por la amenaza que suponía una práctica religiosa que se desarrollara fuera del ámbito del control centralizado y fiscalizado por la autoridad eclesiástica" (Rodríguez 248).

Se puede entrever así que los conventos darán la posibilidad de que algunas mujeres desarrollen su creatividad e inteligencia y disfruten de un alto grado de libertad como en ninguna otra institución colonial. Los archivos religiosos darán cuenta de ello: "crónicas, obras literarias de contenido muy diverso, tratados

\footnotetext{
${ }^{12}$ En el caso de Hildegarda, Épiney y Brunn señalarán que se trata de "una visionaria excepcional que supo ilustrar con singular vigor los datos de la historia de la salvación, aportando a ella algunas perspectivas originales para la época: por ejemplo la importancia a la vez física y espiritual de la feminidad". Respecto a las beguinas plantearán que uno de los rasgos más llamativos de sus escritos "es su carácter a la vez especulativo y experimental. El simbolismo del amor cortés se fusiona en ellas con la expresión metafísica del amor a Dios, gracias a su cultura tanto profana como religiosa. Esta fusión es debida en buena parte a la influencia cisterciense" (Épiney 23-24).
} 
espirituales, biografías de monjas notables" (Foz y Foz 17) se incluyen entre las producciones que podrían circular en estos ámbitos conventuales y que posibilitarán el despliegue de ciertas cualidades literarias y ciertos ejercicios de "descubrimiento" de lo femenino. Esta producción escrita pareciera vislumbrarse como la posibilidad de constitución de un sujeto escritural que si bien no necesariamente resiste a los ordenamientos consolidados en la Contrarreforma, por lo menos sí pone de manifiesto el hecho de que los discursos ordenadores no logran necesariamente operar su control con la efectividad y extensión deseada por los contrarreformistas.

Entre los siglos XVII y XVIII, se empezaba a evidenciar la ocupación de nuevos lugares por parte de las mujeres, dejando atrás la limitada presencia de mujeres españolas y dando paso a la conformación de un importante sector de mujeres criollas, sobre las cuales se inscribirán las virtudes que derramará Dios en estas tierras (Borja, "Santidad" 24). Ello no supondrá necesariamente el reconocimiento de la mujer per se, sino por aquellas cualidades que la distinguen de lo que habitualmente se espera de ella. Al respecto se dirá de Jerónima Nava y Saavedra:

Doto Dios Nuestro Señor a nuestra Gerónima de realsadas prendas naturales. Pues tuvo un cuerpo alto mui proporsionado; su rostro fue mui hermoso, sus ojos fueron mui bellos y vivos. Correspondía a esto que su entendimiento fue mui claro, subtil, delicado y vivo [...] no era entendimiento mujeril [...] tuvo un porte muy discreto, juntando una afavilidad cariñosa con un modo de severidad respetable y assí sus pláticas correspondían a su entendimiento, siendo de su gran juisio, mucha melosidad y bastante donaire [...]. (Robledo 37-38).

De fondo, pues, se tratará de que este cúmulo de virtudes se construya en los espacios conventuales, pues se espera que las mujeres vivan "en el recojimiento que debe una esposa de Christo" (Robledo 38). Recogidas y tapadas, las mujeres coloniales habitan una variedad de clausuras, "su espacio: el de un cuerpo que debe ser circundado, cerrado en sus orificios, su función: la maternidad y la educación de los hijos o el servicio a Dios" (Ferrús 45). En el espacio de una "ciudad ordenada" ella es la más controlada ${ }^{13}$.

\footnotetext{
${ }^{13}$ La sociedad colonial ideó toda una serie de "recogimientos" (beaterios, cárceles privadas, internados, etc.) para amparar a viudas, divorciadas, huérfanas y a todos aquellos grupos de mujeres que escapaban de la opción dual que su mundo les brindaba: el matrimonio o el convento (Muriel 45).
} 


\section{Los conventos y la reclusión}

Las experiencias de las beatas coloniales plantean la necesidad de reglamentación, toda vez que pueden constituirse en la emergencia de una autonomía que podríamos denominar como inesperada. En ese sentido, el control de estas experiencias es necesario "para que no se diga de ellas [...] que cada una vive y hace lo que quiere y que para esto se hacen beatas: para vivir a su voluntad y no tener sujeción a nadie" (Ramón 69). Dada la posibilidad de emergencia de "situaciones fuera de control", donde las beatas se mortificaban, apelando a todo tipo de cilicios y a restricciones de distinta índole; se torna necesario reglamentar esta experiencia "tan personal", de modo tal que se logre evitar tanto un ejercicio de autonomía como una entrada del demonio:

Sus persistentes ayunos y mortificaciones, en sí mismos admirables, se [podían convertir] en la brecha invisible por donde se introducía el demonio en su camino espiritual para precipitar su caída [...] debían rogar a Dios por que no se les dieran visiones. (Ramón 69).

Se implementa con ello la precaución, el temor y la duda hacia estas experiencias, tanto en las beatas como en las monjas. Así lo narra Jerónima:

Sucédeme en otro modo que tengo esperimentado lo que diré; y esto lo causa el grande amor y miedo que tengo de ser engañada, que, en representárseme alguna cosa (hablo siendo en la ymaginasión) no espero a ver el fin de esto. Si a mi pareser sierro los ojos y procuro repelerlo, sin más que reselarme si será bueno o mal; y esto me parese a mí que será repugnar a la voluntad de Dios [...] quedo con alguna duda de si serán de Dios o si serán ylusorias [...] y mientras mayor es la merzed que Dios me haze, tanto es mayor la duda que yo tengo. (Robledo 57).

El hecho de que no todos los arrebatos, éxtasis y demás experiencias fueran catalogados de espirituales y que muchos resultaran más un síntoma de una melancolía envolvente y no de una cercanía con Dios, y en tal caso más una herejía, constituye una necesidad de ordenar y hacer ordenador este encuentro con la divinidad ${ }^{14}$.

\footnotetext{
14 "No debemos extrañarnos de que a los místicos les preocupase mucho que la intensa experiencia interior del religioso fuese confundida con los síntomas de la melancolía, pues se daban cuenta de que el mismo camino que los comunicaba con Dios, los podía también llevar al delirio morboso" (Bartra 75).
} 
La necesidad de implementar un control a estas experiencias surge en esencia por la misma razón: reglamentar las posibilidades de trasgresión a un orden fundado por la supremacía masculina. Si se trata de las beatas, se busca operar sobre una "mujer sin dueño que no acepta ninguna de sus funciones tradicionales (esposa, madre, prostituta, religiosa) y se encumbra a la categoría de maestra de espíritu" (Rodríguez 249); en el caso de las monjas de clausura, aún cuando se inserta en un espacio dispuesto por el control masculino-eclesial, se tratará también de vigilar un lugar privilegiado para el encuentro de amplios grupos de mujeres sin la presencia de hombres.

Los conventos femeninos coloniales se constituirán en un espacio importante para que las mujeres de la élite se resguarden ante la maldad del mundo y para que se mantenga este control social sobre la feminidad. El costo que se tendrá que pagar por ello no sólo será en términos del dinero que deben aportar las familias de estas mujeres, sino en relación con el disciplinamiento al que se entregarán las mujeres como parte de su "renuncia al mundo"15. Una opción que incluye el propio sufrimiento corporal con el que se busca poder expiar los pecados del cuerpo social. El convento cumple así, a su vez, una función social y una función simbólica (Glantz, "El cuerpo").

Sin embargo la clausura que plantean estos conventos no va a ser una renuncia plena al mundo exterior. El convento se constituye en un espacio que si bien persigue la clausura, está en constante contacto con las dinámicas sociales, justamente porque es parte activa de la sociedad. Empero, en su interior se crea la posibilidad para resguardar no sólo a las mujeres del mundo exterior y la maldad, sino para que se desplieguen experiencias personales. Estas experiencias irán de la mano de una reglamentación que nuevamente perseguirá la prevención ante el posible desenfreno y desborde de pasiones que involucran.

\footnotetext{
${ }^{15}$ El ingreso en uno u otro convento dependía de la dote que la novicia podía aportar. Este capital, unido al de las otras monjas y al que los propios conventos generaban a través de distintos métodos de financiación (donaciones, artesanía, repostería, etc.), permitía a estas comunidades de mujeres no sólo sustentarse con garantías, sino convertirse en grandes núcleos financieros, que ayudaban con sus fondos a obispos y virreyes (Ferrús). El disciplinamiento incluye una estricta vigilancia del mismo orden que el que funciona en el "mundo exterior". La vigilancia entre compañeras es así fundamental no sólo las escuchas deben dar cuenta de sus conversaciones; la celadora debe cuidar que todas las monjas se recojan en sus celdas a la hora señalada y que no salgan de ellas, así como que guarden silencio, y si salieren por alguna razón las debe acompañar o al menos vigilar que regresen pronto a la celda. Así, cada cargo dentro del convento tiene unas funciones específicas, pero en general vela por la obediencia a la regla y constituciones y por el respeto a las normas internas de la clausura (Quevedo).
} 


\section{FRONTERAS}

de la historia

La tensión entre las normas que buscan la regulación de los comportamientos y las conductas y las prácticas que las contradicen serán evidentes. Por tanto, el contacto con el mundo exterior no era nada ajeno a este tipo de recintos: a través del locutorio, por ejemplo, perfectamente se podían consolidar alianzas políticas o tratar temas de importancia para todo un pueblo. La mujer gozará así de un protagonismo político que, tal como señala Ferrús, jamás hubiera alcanzado en el mundo extramuros: "Con todo ello se logró generar un 'estado de excepción', que subvierte muchas de las claves que regían la vida de la mujer colonial, pero que exige a cambio un elevado precio: la renuncia al cuerpo y la clausura" (51).

Esta importancia de los conventos va de la mano con la dimensión que adquiere como "recinto intelectual" (Arenal), es decir, como un espacio para el ejercicio de la escritura y la creación y como una experiencia de intercambio y adquisición de conocimientos ${ }^{16}$. Éste incluirá el aprendizaje de artes y oficios, la escritura de vida, la artesanía y la lectura de algunos libros para la formación del espíritu ${ }^{17}$. La lectura contendrá: libros de espiritualidad, textos "hagiográficos", sermonarios, epistolarios, libros de horas. Ello estará aunado a las imágenes y a todo un mobiliario específico (reclinatorios, altares), objetos como rosarios, etcétera, con los que se perseguirá la exteriorización del alma, aún cuando ello suponga bordear la herejía (Durán 273).

\section{Las lecturas y las prácticas de sufrimiento y ordenamiento}

Dentro de los recintos conventuales las mujeres tendrán entonces la oportunidad de acceder a la lectura de textos. Tres textos son particularmente comunes en las lecturas de las religiosas en la Nueva Granada y en su formación espiritual: Los

\footnotetext{
${ }^{16}$ Como señala María Piedad Quevedo, el convento será el eje de la constitución de una cultura de la interioridad que interviene en el establecimiento del orden social neogranadino de los siglos XVII y XVIII. "La dimensión intelectual del recinto conventual estaba presente desde el ingreso, ya que a las novicias se les exigían unos conocimientos en diversas disciplinas (canto, lectura y escritura, pintura, bordado [...]) muy superiores a los de cualquiera de sus coetáneas seglares. En el convento la mujer tendría oportunidades de seguir instruyéndose, disponiendo de maestras y de una buena biblioteca; pero también de espacio y tiempo propios" (Ferrús 53).

${ }^{17}$ Como ha señalado Margo Glantz (Sor Juana), la monja debía convertirse en una especialista en "labor de manos" (cocina, bordado, trabajos de artesanía, etc.), para mantener su mente y su cuerpo distraídos de la "mala ociosidad que conduce al pecado". La escritura de vida formaba parte de este mismo grupo de tareas, razón que llevaría a considerar los textos femeninos como carentes de autoría y que conduciría al confesor a tomarlos como material para sus propios escritos.
} 
Ejercicios espirituales de Ignacio de Loyola, el Arte para servir a Dios de fray Alonso de Madrid y la Guía de pecadores de fray Luis de Granada. Estas producciones españolas servirán de guía para los momentos de oración y, junto con los modelos de vida de los Flos Sanctorum, ayudarán a las religiosas en su proceso de incorporación de Dios. Las recomendaciones, las pautas y los ejercicios prácticos que contienen estos textos enfatizarán en el trabajo corporal, respondiendo con ello a las recomendaciones de la contrarreforma: mortificar y exacerbar los sentidos para hacer posible la visibilización del alma.

Estas técnicas promovidas por las lecturas de los manuales españoles y de las vidas ejemplares, combinadas con las imágenes, buscarán más que nada, como señala Durán, inflamar al espectador y al lector $(288)^{18}$.

Es así como los ejercicios espirituales se constituyen como:

Todo modo de examinar la consciencia, de meditar, de contemplar, de orar vocal y mental, y de otras spirituales operaciones, [...]. Porque así como el pasear, caminar y correr son exercicios corporales; por la mesma manera todo modo de preparar y disponer el ánima, para quitar de sí todas las affecciones desordenadas, y después de quitadas para buscar y hallar la voluntad divina en la disposición de su vida para la salud del ánima, se llaman exercicios espirituales (Loyola 23) ${ }^{19}$.

Fray Alonso de Madrid planteará entonces:

La manera de aborrecerse cada uno es que ninguna cosa placentera quiera, ni desee, ni tome para sí, salvo lo que no puede dejar de querer o desear o tomar sin ofender a Dios. Y cuando la tal cosa tomare, por no poderla dejar sin culpa, sea con dolor de su parte; esto es, que, considerando cuán desmerecedor es de todo placer por sus pecados, le pese de recibirlo; pero en cuanto Dios lo quiere, lo reciba con gozo. Ejemplo: Comer, dormir o semejante cosa que trae algún placer nunca lo toméis, ni lo queráis, ni lo deseéis por vuestra consolación o por satisfacer a vuestro apetito. (Madrid 128).

\footnotetext{
18 "Los modelos se constituyen como una preceptiva tanto en lo que se refiere al comportamiento corporal como al diálogo con Dios, esa comunión anímica que al final de su camino de perfección logran alcanzar los místicos y que los aspirantes a la santidad deben ineludiblemente recorrer si pretenden llegar a su meta". (Glantz, "El cuerpo" 194).

${ }^{19}$ La idea de someter la meditación religiosa a un trabajo metódico promovido por Ignacio no era estrictamente novedosa: Ignacio, según Barthés, pudo heredarla de la devotio moderna de los místicos flamencos cuyos tratados de oración reglamentada había conocido, se dice, durante su permanencia en Montserrat (Barthés, Sade 50).
} 


\section{FRONTERAS}

de la historia

El seguimiento de las técnicas corporales que se promueven en estos textos planteará la necesidad de visualizar que en la experiencia mística confluye tanto un proceso de construcción (ciertas disposiciones, movimientos y ejercicios corporales) como un trabajo espiritual. Ambos hablarán de una valoración del cuerpo en virtud de la función social que encarna la gestualidad y en razón de la necesidad de aplicar sobre él técnicas que van desde el movimiento, las posturas y los ritmos y tiempos corporales, hasta los dolores y la mortificación ${ }^{20}$. En ambos casos se persigue favorecer la comunicación con la teofanía ${ }^{21}$.

\section{La fabricación de la experiencia y la necesidad de santas}

Las técnicas corporales que operan por medio de la divulgación de los textos y, como se verá más adelante, en conjunción con la confesión, pondrán de presente la posibilidad de construir experiencias místicas que pongan en evidencia el beneplácito de Dios con los territorios del Nuevo Mundo ${ }^{22}$.

En todo caso, "La idea de santidad se ajusta a unas condiciones culturales muy precisas y [...] el modelo de sujeto ejemplar se acomoda a las necesidades y condiciones particulares de cada sociedad" (Borja, "Santidad" 21).

Es así como la emergencia de santos, o de personas que murieron en fama de santidad, responderá de manera directa a las dinámicas que se viven en cada contexto. De la misma manera que "El creciente énfasis puesto en los milagros

\footnotetext{
${ }^{20}$ Así, en un manual de educación de frailes novicios se dice: "No formó Dios este cuerpo para encarcelar el alma en él, como mal algunos dixeron, sino antes para perfeccionarla para que se pudiese extraer muchas acciones que sin el cuerpo no puede" (Martín de la Vera, cit. en Stoichita 170). Sobre el gesto, la corporalidad y las experiencias de vida mística se pueden encontrar interesantes planteamientos en el ya clásico trabajo de Zumthor (19-20). La gestualidad, las posturas y las composturas de lo corporal serán dicientes no sólo de la experiencia mística - de esa transluminación del alma, por el "encuentro" con Dios-, sino, además, comunicantes de un discurso de ordenamiento que instaura sobre ese gesto y esas posturas corporales, un código social, de amplísimas utilidades normativas. Antes de establecer cualquier comunicación, hay que preparar el espíritu para lograrla, ello incluirá un trabajo enteramente corporal: los flagelos, los cilicios, los ayunos formarán parte de las llamadas "adiciones" útiles para perfeccionarse en los ejercicios propuestos por san Ignacio o en las recomendaciones de fray Alonso de Madrid.

${ }^{21}$ De ahí la vigencia de la pregunta de Stoichita: “¿se adopta tal o cual gesto porque la pasión obliga al cuerpo a arrodillarse, a prosternarse o a juntar las manos bajo el dictado implacable de la teofanía, o bien por el contrario, se hacen genuflexiones, se levantan las manos, se tuerce el cuello y se llora con el fin de ayudar a la teofanía a manifestarse?" (164-165).

${ }^{22}$ Algunos elementos importantes sobre la confesión son desarrolladas en Heidegger.
} 
corporales así como la aparición real de nuevos milagros de transformación corporal tuvieron lugar exactamente al mismo tiempo que la campaña contra el dualismo cátaro" (Walter 175).

La literatura femenina virreinal salida de los ámbitos conventuales será una respuesta a la necesidad de demostrar la complacencia del Creador con estas tierras y su bendición hacia su crecimiento ${ }^{23}$. Los ayunos, el sufrimiento, la enfermedad y el martirio que padecerán tendrán también un significado que atraviesa lo teológico, lo político y lo social: por medio de ese sufrimiento, limpian y responden a los pecados públicos; su sacrificio se dará en virtud de los vicios que recaen sobre el cuerpo social y político de la sociedad en la que viven. Serán, pues, síntoma del cuerpo social ${ }^{24}$. Ello se puede leer en estos padecimientos de Gertrudis:

Prosiguieron atormentandola crueles è incan/ables enemigos, ce//ando de darle fuertes golpes, crueles azotes, $\int$ in que $\int \mathrm{e}$ oyera, hiriéndole $f \mathrm{u}$ delicado cuerpo, terribles mordi/cos, interiors y exterioes, agudi/simas, penetrantes picadas en todo èl; ceñian/elo con tanta fuerza, que le $/ \mathrm{u} /$ pendian la re/piracion, cau/andole gravi/simo ahogo. La privaron de la vifta por muchos dias, y por un año, y algunos meses la tuvieron muda, y por tres dias como muerta, derramandole tanta abundancia de pulgas, como llovidas, tan impo/sible el cogerlas, como el fufrirlas, la paciente que las Jentia, Jin poder/e mober. Tubieronla por muchas horas crucificada en una barrilla de hierro, que le embolvieron en los brazos como si fuera un fuelto liftòn, metiendola debaxo de la cama, para que el polvo la fufocara, y para impedirle el focorro en tan grave tormento: En repetidas veces, por muchas horas fupina, y pue/ta como un fuerte arco, pegada á los ladrillos del fuelo la frente. ¡O terribles tormentos! [...]. (Calvo de la Riba 111-117).

${ }^{23}$ El siglo XVII fue para la literatura femenina virreinal y para el fenómeno beateril iluminista americano lo que el siglo XVI había sido para España, según Ella Dumbar Temple (cit. en Mujica).

24 "En la vida de las religiosas, al menos en la de aquellas que buscan un Dios de sufrimientos, la enfermedad está omnipresente" (Gélis 70). "Ya en el siglo XVIII, la expresión 'sufrir el martirio', tomada en el sentido metafórico, traducía la voluntad de acceder a ese estado envidiable por la enfermedad y el sufrimiento que conllevaba" (Gélis 71). "El siglo XVII, umbral del mundo moderno, oculta a pesar de su majestuosa fachada, resquebrajaduras del edificio ideológico que sustenta el antiguo régimen. En efecto, es cuando la esfera laica empieza a separarse nítidamente de la religiosa, procesos que se manifiesta en la autonomía creciente y la consolidación del poder monárquico en la mayoría de los países occidentales, supeditando paulatinamente a lo religiosos. Tales cambios no podían sino acompañarse de manifestaciones peculiares, sintomáticas y, a la vez, reveladoras de los profundos trastornos que se venían preparando" (Alberro 219). 


\section{FRONTERAS}

de la historia

Toda esa serie de disposiciones, tecnologías controles y técnicas para acercarse a la teofanía están, pues, en directa interrelación con unas dinámicas sociales de las que emergen. Las experiencias místicas de Jerónima y Gertrudis no son ajenas al contexto en el que se desarrollan, no sólo porque la vida conventual está articulada a las dinámicas sociales, sino porque la experiencia corporal, aún la más íntima de todas, se da como resultado de la inscripción sobre sus cuerpos de los ordenamientos y de las urgencias y necesidades sociales. En uno y otro caso se tratará de la tensión entre un discurso que produce santas $-\mathrm{y}$ requiere esa producción - y uno que promueve el máximo control de las experiencias de Dios. Este último, promovido por la Compañía de Jesús, emergido desde Trento, pero articulado a la tradición de Letrán, impulsará un retorno al cuerpo, un espacio para una eventual emergencia de una experiencia individual ${ }^{25}$.

El cuerpo de las monjas es atravesado por el ordenamiento social, su constitución corporal obedece a las marcas que inscriben las normas de comportamiento. Las técnicas corporales van signando el cuerpo, promoviendo un ejercicio de apertura y desasimiento interno que posibilita la entrada de la experiencia de encuentro con Dios. La técnica produce un cuerpo, porque como ley, como dios o como verbo ha empezado a traspasar la corporeidad. El verbo se hace carne en la experiencia mística de las mujeres.

Parte de estos ordenamientos se evidenciarán en Gertrudis y otras monjas:

A/si ve/tidas en lo exterior, viven adornadas de virtudes en lo interior, fiendo $f \mathrm{u}$ celestial fustento el Pan Sacramentado; $f \mathrm{u}$ continuo exercicio la Oracion; $f \mathrm{u}$ perpetua habitación el Coro, y fus recreaciones, las frequentes devociones, e/taciones, Ro/arios, di/ciplinas, cilicios, ayunos, y demàs mortificaciones: Siendo $/ \mathrm{u}$ Mona/terio la Ciudad, y alto Miftico Monte Siòn, en que fe venera, y honra al Señor, y Divino Cordero. (Calvo de la Riba 49).

Los ordenamientos discursivos se pueden entender entonces como la marca efectuada por el Otro. El Otro simbólico deja su marca en el cuerpo: "función simbólica que interviene en todos los momentos y en todos los grados de

\footnotetext{
${ }^{25}$ Estoy parcialmente en desacuerdo con Echeverría cuando menciona que "la teología tridentina de la Compañía de Jesús reflexiona sobre la vida terrenal — vista como despliegue del cuerpo y sus apetitos sobre el escenario del mundo- a partir de una actitud completamente nueva, diferente a la actitud que la doctrina medieval tenían ante ella" (54). Como bien han mostrado Durán y Rochetta entre la doctrina medieval y la "moderna" hay menos una ruptura que una continuidad rastreable a través de los planteamientos del Concilio IV de Letrán y los postulados de Trento (Rochetta).
} 
existencia del orden humano" (Lacan 50); su marca atraviesa el cuerpo para constituirlo, ordenarlo y así organizar "los modos de relación con los diversos cuerpos" (Díaz 100). Al ser marcado por el Otro, el cuerpo además es sujetado a él; por lo tanto, es una marca que atraviesa todo el cuerpo y que deja sus trazas registradas en todas las dimensiones del cuerpo:

El Otro, como significante y como Ley, al dejar huella en el cuerpo lo signa en lo real, en lo imaginario y en lo simbólico con las rúbricas de la vida y de la muerte; del deseo y del goce; de la filiación, de la diferencia sexual, de la identificación, de la sexualidad, del erotismo (Díaz 100).

Y me paresía que llegaba a mí y me echava al cuello una cadena de finísimo oro y dava tres bueltas con ella a mi cuello y que me sellava las mejillas con una $\mathrm{S}$ y un clavo bajo al corazón. Y tomóle en sus manos dejando en las mismas letras esculpidas; y más abajo puso un "Jesús". Con este favor quedé con mayores ansias de servirle y de rendirme a su santísima voluntad. (Robledo 54).

Aviendo comulgado un día le rogué no se fuese de mi corazón por todo aquel día. Y le sentía en él como recostado descansando, causando en mi alma unos deleites y gosos que parese que ya se quería salir ella de mi cuerpo, o que io no tenía capasidad para cupieran en mí aquella máquina de avenidas tan suaves. (Robledo 104).

Los ordenamientos discursivos por lo tanto, inscriben sus marcas bien dejando sus huellas sobre lo real del cuerpo, bien operando como transformación de su componente imaginario, o bien signándolo en su representación, operando sobre lo simbólico. En todo caso, el cuerpo es el lugar privilegiado para la inscripción de estos ordenamientos, sus marcas se registran siempre en estos tres órdenes. Indistintamente de si opera con dolor sobre la carne, sobre los órganos o sobre los orificios de este cuerpo, o si interviene a través de la corrección y la disciplina, esta inscripción se efectúa siempre en el cuerpo:

No fue menos exacta en venerar a nuestra Ama y Señora la Santa Virgen María. $¡ O$ Madre de Dios! Y deseando infundir en todos esta tan importante como devida devosión, hiso fabricar tres letras de fierro: una S., un ^ y una M. Que significasen ser esclabos de María. Y puestos los heresillos al fuego imprimió las tres letras en la palma de su braso siniestro. (Robledo 47).

En ese sentido, se puede entender el cuerpo como una "superficie de inscripción, emisor, portador y transmisor de signos" (Blair 91); es un lugar donde se inscriben los discursos ordenadores, discursos de poder corporeizados. El cuerpo logra tal condición, se constituye como tal, en virtud de esta 


\section{FRONTERAS}

de la historia

inscripción significante: "el cuerpo se presta a recibir la marca significante, a ser un lugar de inscripción a partir del cual va a poder ser tomado en cuenta por sí mismo" (Soler 17) ${ }^{26}$.

Hasta que pulsada de su Esposo, e instigada de su consciencia, como dise en sus escritos, a los treinta y tres años seis messes y quince días de su edad, en dies de nobiembre año de mill seissientos y dos, la recogió su Esposo para sí rindiéndola por el medio de la gravíssima enfermedad que le dio a padeser por espacio de dies años cabales (como dise en sus escritos le fue signficado), en que me aseguró era indesible lo que padessió, assí en su interior, como en lo exterior, allándose mui a menudo con agonías mortales; pues entre lo mucho que padesió, fue acompañado casi continuamente con el acsidente de aogo. (Robledo 38).

\section{Esto es mi cuerpo (o de la escritura de experiencias ejemplares)}

Las experiencias vividas son plasmadas a través de un ejercicio de escritura, y si bien no se piensan como objeto de divulgación, terminan siendo de conocimiento "público" toda vez que en ellas se plasman modelos de vida ejemplar. La construcción de estos textos responderá a su vez a modelos de comportamiento; se basará en patrones de vida santa (Ibsen). En esa medida plantea Ferrús:

La monja colonial, que escribe desde el mandato confesional, no debe distinguirse en su escritura, la singularidad es una falta de humildad; sino perderse en el flujo de una tradición y de un linaje que justifican la toma de la palabra [...] "parecerse a", puede ser una forma de salvarse; pero también, de alcanzar el reconocimiento que permita, a su vez, transformarse en modelo. (38).

El ejercicio de escritura va a estar mediado además por el confesor. Empujadas por ellos a la escritura de su experiencia como ejercicio de confesión, sus palabras se convertirán en testimonio, sus anotaciones se emplearán como elemento para juzgar la verdad y el grado en que se desvía o no esa experiencia; al tiempo serán utilizadas como materiales para la redacción de futuras biografías.

Las vivencias místicas de las monjas latinoamericanas coloniales podrán entenderse como la evidencia de los intereses del criollismo naciente, a la vez

\footnotetext{
${ }^{26}$ Otra interpretación de las marcas sobre el cuerpo desde el psicoanálisis, se puede ver en Anzieu.
} 
que como un ejercicio de subjetivación, una puesta en evidencia de $\operatorname{sí}^{27}$. Si por medio de las técnicas corporales y los ordenamientos sociales el cuerpo de las monjas ha sido atravesado y signado, es por medio de la escritura como este cuerpo emergerá poniendo de presente un plus al requerimiento eclesial de la confesión o al modelo ejemplarizante: se trata de la experiencia personal de la escritura, de la vivencia individual del sufrimiento.

De ahí es entendible la angustia de Gertrudis por no poder confesarse, que plasmará en sus escritos:

[...] Yo à nadie quiero re/ponder, buelvo a mi Padre, à quien naturalmente e/crivo[...] [...] Sì fon cofas de Dios, còmo e/tas me ponen tan oprimida, que me alexan mas de Dios, y e/pero alexamiento eterno por ellas [...] [...] yo sè que pecados tengo, y que la fuente que los laba es la confe/sion, e/ta no la hay, ni hallo como, folo la de/eo: Si en e/tos e/critos fe ha dicho tanto, en todos me confie/fe, que es lo mas proprio, que yo de/eo; ya vè, que e/torbos, que males exteriores, y interiores; que fe vale el demonio de criaturas, y de lloverme tentaciones para hacerme tanto daño: Todo efto Dios lo sabe, y lo ve: Si me dicen, que e/criva, que me ayudara, adonde $f$ i fon cofas ciertas, e/tas las ayudas, y movimientos, entonces me dexan mas en el mayor aprieto, que nada puedo mas que fentir, padecer el de/amparo de Dios, y no moverme a lo que mas defeo, y manda haga, ò dice Vmd. son cofas de Dios, ò Santos, que lo mandan, ò dicen, que ayudaràn: adonde e/tà e/ta ayuda, quatro dias fiquiera de paz, ò $/ 0 /$ siego; que la confe/sion, y mi conturbacion, aun para una reconciliacion de veniales la nece/sitaba [...]. (Calvo de la Riba 203).

Esta experiencia se verá favorecida por una serie de "medios" que permiten desarrollar una piedad más personal y más interior. El ejercicio de la lectura personal y la necesidad de auto-reflexividad demandada por el ejercicio de la confesión, serán importantes en ese proceso de "emergencia subjetiva". Ello también va aunado a que se cuenta con una variedad de objetos, mobiliario y libros indispensables que permiten ejercitar una piedad individual distinta de aquellas prácticas colectivas y externas. (Durán 289).

\footnotetext{
27 "Este conjunto de sueños y visiones aquilata a las monjas así favorecidas durante su camino hacia la perfección: tiene carácter de presea, es la afirmación, la corroboración que muestra la predilección de Dios, su Esposo, por ellas. Esa marca, esa predilección las señala, las aparta del resto del rebaño, muestra públicamente los designios del Señor, revela su presencia cuando manifiesta con señales la elección y la corrobora con el premio recibido, designado con el característico nombre de finezas" (Glantz, "El cuerpo" 198).
} 


\section{FRONTERAS}

de la historia

Una promoción tal se desarrolla en doble vía: hacia un lado las monjas desarrollan una piedad más personal, hacia el otro, se estimula la incorporación de la "obstetricia espiritual". (Durán 320).

Los preceptos que guían la experiencia religiosa de estas monjas son, en primer lugar, susceptibles de ser adecuados a la propia personalidad de cada una de ellas, aún cuando se espera que no se traspasen los límites del modelo. Ello es así porque las experiencias místicas implican un encuentro singular con Dios, inscrito en el cuerpo y vivido corporalmente. Esa vivencia corporal trae de la mano una experiencia subjetiva; va aunada a una experiencia individual no sólo por el hecho de que se entrecruza con la oración mental o con el desarrollo del sentimiento de culpa, sino, sobre todo, porque las experiencias corporales de estas mujeres promueven la conciencia de ser y tener un cuerpo. Esa es la condición para ofrecerlo. La manera de sentir ese cuerpo se ve favorecida por las técnicas corporales que involucran un sufrimiento exacerbado, una mortificación de los sentidos, a la manera de San Ignacio $^{28}$.

Esta composición de lugar ignaciana es al mismo tiempo la corporeización de la experiencia religiosa. Lo que se construye aquí más allá del infierno es el cuerpo del que vive la experiencia de estar sintiendo el infierno. Lo que se promueve, por lo tanto, en el proceso de disciplinamiento de la monja será sobre todo experiencia de su cuerpo y, por lo tanto, experiencia de sí. En cuanto experiencia barroca, ésta será una puesta en escena del cuerpo: un ofrecimiento a través del texto por intermedio del sufrimiento corporal. Dirá Barthés: "Los 'misterios' delineados por Ignacio en el relato crístico tienen algo teatral que los emparenta con los misterios medievales: son 'escenas' que al ejercitante se le pide vivir, a la manera de un psicodrama” (Sade 68).

\section{La construcción de corporeidad y subjetividad}

La experiencia de Dios es experiencia corporal porque el cuerpo de Cristo es la esencia del rito eucarístico. Entre los siglos XIV y XVIII, como bien ha mostrado Gélis, toda una madeja de ritos y creencias se va injertando alrededor del cuerpo sufriente de Jesucristo. El cuerpo sufriente se articulará alrededor de

\footnotetext{
28 "El cuerpo de que se trata en Ignacio no es nunca conceptual: es siempre este cuerpo: si me transporto a un valle de lágrimas tengo que imaginar, ver esta piel, estos miembros entre los cuerpos de los animales y percibir la infección que sale de ese objeto misterioso cuyo demostrativo (este cuerpo) agota la situación, ya que el nunca puede ser definido sino designado" (Barthés, Sade 69).
} 
las escenas de la Pasión; éstas simbolizan el recorrido doloroso del Redentor y cada uno de ellos recuerda, por su materialidad, un momento del envilecimiento de su cuerpo (Gélis 33).

Una multiplicación exacerbada de esos signos será efectuada desde la Contrarreforma, materializando con ello parte de la estrategia que reivindica el cuerpo (en su sufrimiento) como camino para el alma. El simbolismo que se promueve desde allí convoca, atrae y deleita. Las imágenes (de heridas purulentas y en carne viva, de chorros de sangre que inundan el torso y las extremidades, de un cuerpo humillado), serán contundentes y causarán a un tiempo consternación, provocación, arrepentimiento y un inusitado "gusto morboso" que movilizará aún más las pasiones (Gélis 37-38). Así, el cuerpo puesto en escena será a un tiempo promotor de la fe, potenciador de experiencias místicas y multiplicador de modelos de vida en los que se imitarán esos padecimientos vividos por Cristo.

En ese sentido, la mortificación del cuerpo provocará, además de la interlocución personal cuerpo a cuerpo con Dios, "Una serie de visiones, signos reveladores de una comunicación establecida con lo divino; comunicación mantenida con la condición de que la mortificación sea continua y su ejercicio adecuado permita la reiteración de las visitas y del consiguiente diálogo entre divinidad y ejercitante" (Glantz, Sor Juana 196-97). La mortificación podrá favorecer así el desarrollo de experiencias místicas.

Lo que se logra con estos métodos, por lo tanto, es un diálogo íntimo con la teofanía; más allá es un nuevo "idioma" para establecer una comunicación entre Dios y las personas. El sufrimiento constituirá la esencia de esa nueva lengua, entremezclado con el erotismo, signo igualmente evidente de esa emergencia de conciencia corporal, de esa emergencia subjetiva ${ }^{29}$.

La subjetividad que emerge lo hará también en virtud del ejercicio de la confesión y de la oración personal. Una y otra se inscribirán también en la tradición medieval y serán promulgadas por los evangelizadores a los nativos americanos y por el clero durante los siglos XVI y XVII a todos los fieles ${ }^{30}$.

\footnotetext{
${ }^{29}$ Señalará Barthés que para el caso de los ejercicios de Loyola es posible entrever en sus objetivos la invención de una lengua (Sade 55).

${ }^{30}$ Después del siglo XII, dice Durán, el laico aprende a orar en privado: “Antes no lo sabía hacer, hasta el siglo XIII sólo sabe el Padre Nuestro y la primera parte del Ave María, no dialoga con
} 


\section{FRONTERAS}

de la fistoria

Vol.12 / 2007

\section{El sufrimiento que se inscribe es sufrimiento que se escribe}

Como se ha mencionado en los apartados precedentes, el sufrimiento corporal es el medio con el cual empieza a emerger una conciencia de sí. Ello supone, por lo tanto, que es en virtud de los padecimientos autoinfligidos y de las doloras experiencias de Dios como esa subjetividad empieza a tener algunos visos. Ese sufrimiento hecho texto supone mucho más tanto del ejercicio de confesión por el que ha surgido, como de la autorreflexividad que promueve. Este plus tiene que ver con hacer del sufrimiento que se inscribe en el cuerpo, del martirio que se ha materializado en la corporeidad, un objeto para el otro.

\section{$\mathrm{Al}$ respecto se dirá de la vida de Gertrudis:}

Ceñidas fon las noticias que doy en la relacion de fu fingular Vida. Llegue, pues, e/ta à la pren/a, para que corra tan generoso vino para alivio de las Almas. Difundan/e fus fuaves olores para fortalecerlas, fiendo todo e/to efecto participado de la Vid Chrifto nueftro Bien. (Calvo de la Riba).

Ya se ha dicho hasta aquí que la letra (en cuanto ley, ordenamiento y discurso) se materializa en la carne ${ }^{31}$. Lo que las monjas encarnan es la literalidad de esa inscripción en su cuerpo. Así, esa encarnación, materializada corporalmente, se hará texto para el otro. La experiencia mística ha inundado la carne haciendo de este cuerpo femenino un texto. El cuerpo entonces deviene textual y su textura está hecha de letra (Bercovich 33). Una letra que circula como mensaje que ejemplifica y deleita. Es pues un cuerpo, un dolor, que deviene saber y goce ${ }^{32}$.

Dios en la intimidad, el desarrollo de una religiosidad interior (siglos XIII al XV) comenzará a partir de estas fechas cuando las órdenes mendicantes (dominicos y franciscanos) difundan toda la mística del rosario, que conlleva la interiorización de los sufrimientos de Cristo en su pasión y muerte" (269).

${ }^{31}$ Dice Rubial: "La asociación de lo femenino con la carne y de lo masculino con el espíritu provocó que las mujeres recibieran un especial tratamiento hagiográfico, pues su cuerpo era el paradigma de la presencia de lo sagrado en lo corpóreo [...]. Así, las mujeres, más propensas a somatizar la experiencia religiosa y a utilizar su cuerpo como un instrumento místico, se convertían en el receptor espiritual ideal gracias a su capacidad para manipular el sufrimiento" (27).

${ }^{32}$ Cada uno de los padecimientos corporales de los místicos comunica la santidad del alma de estos seres bienaventurados; en sus sufrimientos (y en la representación de sus sufrimientos), circulan los modelos de vida ejemplar, fluyen mensajes sobre las maneras en las que el alma se exterioriza a condición del padecimiento corporal. Desde allí se entenderá cómo, a partir de un 
A través de la narración de estas experiencias circula lo sagrado —un saberque fluye y que atrapa - un goce ${ }^{33}$. En estos textos se podrá leer no sólo el dolor y sufrimiento padecido por estas mujeres, sino un discurso del cuerpo; se podrá leer, sin más, aquello que, en una insistencia por inscribirse, no cesa de escribirse. Este escrito se logra a condición de rasgar la intimidad del cuerpo, de irritarlo con sus estigmas, de signar la carne con los cilicios y las disciplinas, en fin, de inscribir en él el síntoma social de una cultura barroca urgida de sufrimiento, necesitada de una expiación de sus culpas. Por esta escritura emergerá una subjetividad, pero entendida no como la liberación del individuo, sino como la sujeción de éste en el orden social ${ }^{34}$. Al escribirse, se inscribe justamente en el ordenamiento social, ya que su texto será siempre texto para el otro, modelo de vida, patrón de comportamiento, ordenamiento para el otro ${ }^{35}$. El sujeto como tal es "efecto de sus propios textos. Textos hechos de imagen, de acto o de carne. La escritura del sujeto litoraliza lo real" (Bercovich 35).

Es así como la literatura "hagiográfica" y en general de vidas ejemplares se evidencia como "Un aparato doctrinal de predicación (cuyo objetivo es hacer creer y actuar correctamente) que se echa a andar desde el siglo XII y que la imprenta [logrará] difundir [luego] en mayor número" (Durán 335).

Los textos que escribirán los confesores no sólo serán hechos desde su experiencia personal, sino fundamentalmente a través de esos textos de confesión, de esas cuentas de conciencia que les solicitan a sus dirigidas; con ello lograrán no sólo controlar y mantener la ortodoxia de las visiones, los éxtasis o cualquier otra manifestación virtuosa, sino además conocer lo que Dios manifestaba por medio de estas elegidas y que ameritaba, por lo tanto, darse a conocer (Borja, "Santidad" 28).

cuerpo atormentado, se transita hacia un texto didáctico: se pasa de un dolor a un saber (Certeau, La fábula 213).

33 "[...] que lo sagrado hable es algo que siempre impresiona a los fieles y fortalece las devociones" (Gélis 48).

34 Dirá Michel de Certeau: "La desaparición del Primer locutor crea el problema de la comunicación, es decir de un lenguaje por hacer y ya no sólo por escuchar [...]. Dicho de otra forma, por perder su sitio, el individuo nace como sujeto. El lugar que antes le fijaba una lengua cosmológica, entendida como "vocación" y colocación en un orden del mundo, se convierte en una "nada", una especie de vacío, que empuja al sujeto a dominar un espacio, a plantearse a sí mismo como productor de escritura" (La invención 151).

${ }^{35}$ La escritura opera aquí como trazo unario, "es decir, como marca de inicio; como inscripción en el marco del lenguaje" (Morales 47). 


\section{FRONTERAS}

de la historia

En este inexplicable penar llegò [...] de/eo/a de con/fesar/e para comulgar el dia figuiente [...] y cumplir con la Igle/ia, no pudo executarlo, ni yo con/eguirlo, cooperando à fus fervoro/os de/eos con todos los medios que pude: dixele, experimentando /u impo/ibilidad, al de/pedirme: Maria, hay tienes la Imagen de Jesvs, Supremo Sacerdote, confie/fate e/piritualmente con èl. Hizolo obediente, pernoctando en fervoro/os clamores, pidiendole con tiernas lagrimas le concediera confe/sion y comunion. Y tomando la pluma, que era $/ \mathrm{u}$ lengua, le hizo a Maria Santifsima e/ta tierna exclamacion, y fervoro/a petición [...]. (Calvo de la Riba 162).

La subjetividad que emerge lo hará entonces con unos visos de la conciencia de sí, que trazarán las señales esenciales de la identidad criolla, una identidad sostenida en el reconocimiento de un "yo" pero que se da sólo como punto de partida de la entrada a un ordenamiento donde ese "yo" deberá ser sacrificado. La narración de estas vidas ejemplares reflejará también ese ofrecimiento y desasimiento interno. Es así como en el seno de una cultura barroca empiezan a aparecer "las primeras evidencias de una conciencia social diferenciada en el seno de la sociedad criolla" (Moraña 27). La escritura vendrá aquí a atravesar ese cuerpo para dar cabida a esa conciencia social. En esa medida, la escritura será a un tiempo herida y acto creador, ambas metáforas corporales femeninas ${ }^{36}$.

En ese complejo universo de la productividad barroca, las vidas de monjas colocarán en escena un cuerpo que se transformará en la matriz del relato, trabado por el sentido último de cumplir el programa de imitatio Christi. Desde aquí, el lenguaje corporal se presentará como otro decir; una alternativa a la palabra oficial, un lenguaje encubierto que también descubre la especificidad de la expresión femenina: "Cuerpos que imitan a Cristo, pero que son cuerpos de mujer, hablan de un deseo y de una identidad femeninas, allí donde éstas deberían ser borradas. Textualidad y sexualidad se traban sobre un continuum, resultado de una concepción específica del texto y del cuerpo" (Ferrús 9).

Los conventos abrirían una posibilidad importante para la participación de las monjas no sólo en la vida económica y política, sino en la vida intelectual y social, en el sentido de que el ordenamiento al que entra por las puertas conventuales abrirá las del ejercicio escritural. Una vez más, será evidente la necesidad de signar el cuerpo con la marca - herida que supone este ordenamiento para que la escritura produzca - fecunde subjetividad. Una mujer

\footnotetext{
${ }^{36}$ Véanse Nasio, Siles del Valle y el capítulo que dedica Ferrús a la escritura como herida.
} 
que emerge en cuanto criolla, pero que lo hace en virtud de su ofrecimiento sacrificial.

\section{Evidencias de una subjetividad emergente: no hay cuerpo sin sujeto}

Si en el ejercicio escritural emerge una conciencia de sí que traza los visos de una subjetividad, ello sucede porque tal ejercicio se ha dado, como se ha dicho hasta acá, a condición de que el cuerpo sea atravesado por esa experiencia de Dios, lo que se ha logrado en virtud del seguimiento de ciertas técnicas espirituales que son esencialmente corporales. El sujeto que emerge en el ejercicio escritural de las monjas, lo hace esencialmente porque exacerba sus sentidos al estilo ignaciano y porque coloca su cuerpo al servicio de esa retórica de la marca ${ }^{37}$. El cuerpo así signado por el Verbo, posibilita antes que la conciencia de sí, la conciencia de tener y de ser un cuerpo. En esa medida, se abrirá paso a la transición del "yo-cuerpo" al "yo-sujeto",38, toda vez que insístase en ello- no hay cuerpo sin sujeto. Esta transición hablará de una puesta en evidencia de lo femenino, pero para el contexto de la Nueva Granada será también la puesta en escena de lo criollo ${ }^{39}$. Al afirmar esta otra conciencia del cuerpo que se emancipa y se separa del gran cuerpo colectivo (pero que lo logra justamente a condición de haber sido signado por él), paga cara su emancipación ${ }^{40}$. Ese cuerpo emancipado no sólo tendrá que confrontar su soledad y desamparo, sino que además tendrá que enfrentar la evidencia de que

\footnotetext{
${ }^{37}$ Sobre la subjetividad emergente (aunque en contextos distintos al que desarrollamos en este artículo) cuatro textos son particularmente llamativos: el primero, el trabajo realizado por Brigante et al. acerca de la producción de subjetividad en el arte de Luis Caballero y Lorenzo Jaramillo; el segundo, el ya clásico de Búfalo; el tercero, el trabajo realizado por Bürger, y el cuarto, el divulgado artículo de Guattari.

${ }^{38} \mathrm{Al}$ respecto véase Kristeva.

39 "El Barroco de Indias se corresponde históricamente con el proceso de emergencia de la conciencia criolla en los centros virreinales desde los que se establecían los nexos económicos, políticos y culturales con el poder imperial" (Moraña 31).

${ }^{40}$ Esta conciencia, siguiendo la metáfora del barroco de la vida como un gran escenario, se dará en virtud de poder mirar en la creación, como dice Echeverría, una obra en proceso, un hecho en el acto de hacerse; proceso o acto que consiste en una lucha inconclusa, que está siempre en trance de decidirse entre la luz y las tinieblas, el bien y el mal, Dios y el diablo (54). Esto supondrá distinguir en ese acto de creación constante un "lugar necesario, funcionalmente específico para el ser humano: el 'topos' a través del cual y gracias al cual esa creación alcanza a completarse como 'el mejor de los mundos posibles'. Como libertad, como libre albedrío, como capacidad de decidir y elegir, y no como cualquier otro ente, el ser humano, tiene su importancia específica en y para la obra de Dios" (Echeverría 54-55).
} 


\title{
FRONTERAS
}

de la fistoria

su "soberanía" es menos la exteriorización de una autonomía y más la entrada en un nuevo orden social. En esa medida, compartimos ampliamente lo expresado por Moraña cuando señala:

\begin{abstract}
Este momento de emergencia de las que podríamos llamar formas de conciencia subalternas por su ubicación dentro del aparato político-social de una época es un proceso de difícil lectura. En primer lugar, porque esa misma posición de subalternidad condiciona el grado de formalización y homogeneidad que ese discurso puede alcanzar. En segundo lugar porque la evidencia histórica de ese proceso, la posibilidad de documentación del mismo, implica la interpretación de indicios que, expresados muchas veces con el lenguaje y la retórica dominantes, se mimetizan con la visión del mundo hegemónica, la remedan, parodian o utilizan para sus propios fines. (Moraña 31).
\end{abstract}

Ello entrará en plena concordancia con el postulado jesuita según el cual "El comportamiento verdaderamente cristiano no consiste en renunciar al mundo, como si fuera un territorio ya definitivamente perdido, sino en luchar en él y por él, para ganárselo a las tinieblas, al mal, al diablo" (Echeverría 55). Pero donde esa lucha supone el ofrecimiento de sí para ganar la batalla.

\section{Cuerpo que fue entregado (o acerca de ser miembros de un mismo cuerpo)}

El cuerpo que se pone de manifiesto - en evidencia - con la exacerbación de los sentidos, ese cuerpo atravesado por la letra, herido en su unidad, emerge entonces fragmentado en la escritura. En su emergencia, si bien gana en "conciencia de sí", no lo hace a la manera de un gran ego que trascurre en el mundo con plena libertad: todo lo contrario, esa conciencia de sí, supone la entrada en un nuevo ordenamiento: aquel que identifica a la modernidad y que viene amarrado del autocontrol. Este despojo es condición sine qua non para la experiencia de encuentro con la teofanía, pero es al mismo tiempo la entrada en un nuevo ordenamiento: un alto precio que habrá que pagar por este encuentro.

Yo entonses me entregué más, me procuré rendir más y me arrepentí de mi obstinación, deseando naser en aquel ynstante para dedicarme toda aquel Señor, el qual, alargando su mano derecha, me sacó el corazón y con la otra sacó el suyo de su amoroso pecho y me lo dio, poniéndolo con sus mismas manos, en el hueco que avía quedado. (Robledo 65).

Es así como la constitución de esa conciencia que permite la autorreflexión, la autovigilancia o el autocontrol se da siempre y cuando haya un yo (yo-cuerpo, 
yo-sujeto) que incorpore e interiorice esas normatividades. Lo que perseguirá el proceso de incorporación e interiorización será, no obstante y paradójicamente, la supresión de los rasgos singulares de ese sujeto emergente.

En el marco de un barroco de Indias, este proceso se pondrá en evidencia en la medida en que este paradigma barroco, como señala Moraña, ponga de manifiesto la expresión de una subjetividad criolla y, a la vez, la puesta en circulación de los códigos culturales metropolitanos imperiales. De tal modo, esa conciencia criolla emergerá a condición del uso de esos códigos del imperio que servirán "no sólo para hablar por sí mismos sino de sí mismos, de sus proyectos, expectativas y frustraciones" (Moraña 37), pero que al mismo tiempo, los inscribirá justamente en los códigos imperiales. Si el barroco permite por intermediación de la apropiación de un acervo de códigos peninsulares la emergencia de una subjetivad, dicha emergencia será más que nunca subalterna ${ }^{41}$.

Para las monjas, su experiencia mística servirá como espacio de expresión y actuación pública dentro de una historia política, económica y social y dentro de la literatura neogranadina. Paradójicamente se dirá que el carácter de desasimiento interno propio de la mística, y de pérdida de las fronteras entre sujeto y objeto, favorece a la mujer (Irigaray). Representarse a imagen y semejanza de Cristo sufriente y ofrecer sacrificialmente el propio cuerpo abrirían aparentemente el espacio en el que la mujer empieza a constituir rasgos de su búsqueda de autonomía ${ }^{42}$. Sin embargo, es posible plantear también que esta conciencia de sí que abriría un desasimiento interno (ofrecimiento del cuerpo) encadenará el goce femenino más que nunca al orden masculino. Si bien abre la posibilidad de pensar que a través de estas experiencias fluye la

\footnotetext{
41 "En la práctica literaria de algunos escritores del siglo XVII hispanoamericano, el código barroco sirve como vehículo para cantar la integración al sistema dominante, lograda o anhelada. En otros casos, el modelo barroco provee las formas y tópicos que, utilizados por la intelectualidad virreinal, denuncian la Colonia como una sociedad disciplinaria y represiva. Ésta por un lado, tolera la ascensión criolla, por otra parte inevitable; al mismo tiempo, intenta controlarla como parte orgánica del proyecto imperial, enajenándola de su realidad cotidiana a través de los rituales y las máscaras de poder" (Moraña 36).

${ }^{42}$ Dirá Ferrus: "La vida conventual se vincula a la confesión y trabaja sobre el secreto. Escribir desde la obediencia supone inscribirse en un discurso de poder, evidenciar sus pliegues. Pero este gesto se torna ambivalente, pues desde aquí es posible desatar una estrategia que haga pasar a los ojos de la autoridad un gesto discursivo que de otra manera podría entenderse como subversivo. La mujer logra protagonizar el acceso a un espacio de auto-expresión que de otro modo le estaría completamente negado" (63).
} 


\section{FRONTERAS}

de la historia

constitución de la "intimidad femenina", ésta justamente estará enmarcada por la presencia más que nunca activa de Dios. El placer de lo femenino se inscribirá con ello en la intimidad reglada, en la experiencia personal y moderna del autocontrol de las pasiones.

Las monjas místicas no dejan de comportarse como se esperaba que lo hicieran las mujeres; su discurso, aunque puede llegar a entenderse como estratégico y deliberadamente ajustado a la norma - aun cuando transita por la herejía-, no dejará de inscribirse en el orden social establecido y de obedecer al canon exigido.

No obstante, siempre algo del cuerpo escapará a esa apropiación de la vía discursiva y, por lo tanto, su cuerpo no se dará todo al ordenamiento social. El texto producido en principio no deberá decir "nada nuevo", o "casi nada", y deberá ajustarse a los patrones y modelos impuestos. Pero, como comenta Ferrús, "sólo donde los reglones se tuercen emerge la propia identidad" (Ferrús $63)$.

En el mismo ejercicio de escritura se podrá evidenciar, en todo caso, cómo esa emergencia de subjetividad va vinculada estrechamente con la inscripción en un ordenamiento social, aún más complejo:

Cuando la mujer recibe la hoja y la pluma, estará asistiendo a la misma clausura que cuando recibe el velo, si puede escribir es porque ha aceptado dejar de ser mujer para ser monja [...]. Cuando la monja intercambie su condición-mujer por su condición-mística habrá ganado y perdido, el cuerpo ha sido intercambiado por el lenguaje del cuerpo, de la luz y del sueño. (Ferrús 147).

Se tratará, entonces, del cuerpo social.

\section{El cuerpo social y la primera modernidad}

Si este proceso de subjetivación termina favoreciendo la inscripción de los sujetos a un orden social aún más atrapante, es porque no opera solamente en una vía negativa ${ }^{43}$. La complejidad de la normatividad moderna y su agarre

\footnotetext{
43 "Si el poder no fuera más que represivo, si no hiciera nunca otra cosa que decir no, ¿pensáis que realmente se le obedecería? Lo que hace que el poder agarre, que se le acepte, es simplemente que no pesa solamente como una fuerza que dice que no, sino que de hecho atraviesa, produce cosas, induce placer, forma saber, produce discursos [...]" (Foucault, 182). Al respecto, es importante considerar las reflexiones desarrolladas por Pastor.
} 
tendrán necesariamente como fundamento la conciencia de sí; ésta, como hemos intentado señalar en este documento, tiene algunos visos de su formación en la compleja relación que se traza en el barroco colonial entre el cuerpo, el sufrimiento y la escritura ${ }^{44}$. La "conciencia" corporal se vehicula a través del sufrimiento y de esa serie de normatividades que persiguen la clausura, el dolor, la oración personal y la autorreflexión sobre las culpas. En el cuerpo se inscribe así el sufrimiento y un discurso social que son los que posibilitan tanto una producción escritural femenina, como esa "conciencia de sí". Éste ejercicio de producción, sin embargo, no vendrá a ser el escenario para poner en evidencia la autonomía femenina, sino justamente su control y sujeción a las normas eclesiales y a las necesidades de la sociedad neogranadina ${ }^{45}$.

Esta emergencia subjetiva femenina no sólo no será ajena a estas dinámicas sociales, sino que podrá entenderse como síntoma social. En una sociedad como la neogranadina este proceso termina favoreciendo, como hemos visto, el desarrollo de una conciencia criolla que busca posicionarse ante la hegemonía peninsular, pero que, en todo caso, termina sujetada a aquello que ha hecho posible su emergencia. Un camino recorrido en el mismo sentido que lo ha hecho ese sujeto femenino emergente en la escritura de sus padecimientos.

En este marco podemos entrever también de qué manera la Iglesia termina por consolidarse en "Una instancia fundamentalmente re-ligadora, es decir, socializadora $[\ldots]$ precisamente en la medida en que justifica el sacrificio que día a día el ser humano tiene que hacer de sus pulsiones para poder vivir dentro de una forma social civilizada" (Echeverría 57), lo cual se consolidará en punto esencial de la configuración del "paciente" y "sacrificado" sujeto latinoamericano.

\footnotetext{
${ }^{44}$ Alfonso Mendiola plantea que "la escritura moderna, produce, mientras que la otra, la medieval o cristiana, dice el orden". Concluirá Mendiola que por escritura se entiende "la operación por medio de la cual se instituye el sentido en la sociedad. En una el sentido que nos muestra la práctica de la escritura es dado (teológico), en otra es producido (ciencia). La escritura moderna se fundará en la medieval, pero negándola. El origen de la sociedad moderna será, así, la sociedad religiosa; por eso de Certeau insiste en que la arqueología de la sociedad actual es la religiosa" (35).

${ }^{45}$ Aunque, insístase en ello, siempre habrá algo que se resista a este discurso y que también tiene un correlato en el cuerpo.
} 
FRONTERAS

de la historia

Vol.12 / 2007

\section{Bibliografía}

\section{Fuentes primarias}

Archivo General de la Nación, Bogotá, Colombia (AGN).

Policía $(P) 2$.

Juicios criminales (JC) 4, 10.

\section{Fuentes secundarias}

Alberro, Solange. "La licencia vestida de santidad: Teresa de Jesús, falsa beata del siglo XVII". De la santidad a la perversión o de por qué no se cumplía la ley de Dios en la sociedad novohispana. Ed. Sergio Ortega. México: Grijalbo, 1995.

Anzieu, Didier. El yo piel. Madrid: Biblioteca Nueva, 1987.

Aranguren, Juan Pablo. "Buscando goces ilícitos". Repensando a Policéfalo. Diálogos con la memoria histórica a través de documentos de archivo. Siglos XVI al XIX. Eds. Marta Herrera, Camila Aschner y Taina Lizarazu. Bogotá: Editorial Pontificia Universidad Javeriana, 2006.

Arenal, Electa y S. Schlau, "El convento colonial mexicano como recinto intelectual". Actas IBLI. México: El Colegio de México, 1994.

Barthés, Roland. Investigaciones retóricas I, La antigua retórica, ayudamemoria. Buenos Aires: Tiempo Contemporáneo, 1974.

—. Sade, Loyola, Fourier. Venezuela: Monte Ávila, 1977.

Bartra, Roger. Cultura y melancolía. Las enfermedades del alma en la España del siglo de Oro. Barcelona: Anagrama, 2001.

Bercovich, Susana. "La escrituras del sujeto". Escritura y psicoanálisis. Coord. Helí Morales Asensio. México: Siglo XXI, 1986.

Bergamo, M. La anatomía del alma. Madrid: Trotta, 1998.

Bicecci, Mirta. "El cuerpo y el lenguaje". La re-flexión de los conceptos de Freud en la obra de Lacan. Coord. Néstor Braunstein. México: Siglo XXI, 1983.

Blair, Elsa. "El espectáculo del dolor, el sufrimiento y la crueldad". Controversia, 178 (mayo 2001). 
Borja, Jaime. "Santidad y criollismo. Vidas ejemplares en el Nuevo Reino de Granada". Revista Javeriana 142.726 (2006): 18-30.

-. "Tendencias y herencias de la homosexualidad. De la cristiandad medieval a la colonial". Universitas Humanística 29.53 (2002): 95-107.

Brigante Anna María et al. El cuerpo fábrica del yo. Bogotá: Editorial Pontificia Universidad Javeriana, 2005.

Búfalo, Enzo del. La genealogía de la subjetividad. Caracas: Monte Ávila, 1992.

Bürger, Christa y Peter Bürger. La desaparición del sujeto. Una historia de la subjetividad de Montaigne a Blanchot. Madrid: Akal, 2001.

Calvo de la Riba, Pedro Andrés. Historia de la singular vida y admirables virtudes de la venerable madre Sor María Theresa Gertrudis de Santa Inés. Madrid: Philippe Millan, 1753.

Certeau, Michel de. Historia y psicoanálisis. México: Universidad Iberoamericana, 2003.

—. La fábula mística. Siglo XVI-XVII. México: Universidad Iberoamericana, 1993.

—. La invención de lo cotidiano. Vol. 1. México: Universidad Iberoamericana, 2000.

Colmenares, Germán, "La ley y el orden social: fundamento profano y fundamento divino". Boletín Cultural y Bibliográfico 22 (1990): 3-20.

Correa, L. et al. La construcción retórica de la realidad: La Compañia de Jesús. México: Universidad Iberoamericana-El Mundo sobre el Papel, 2006.

De Zuleta, Pilar, "La vida cotidiana en los conventos de mujeres". Historia de la vida cotidiana en Colombia. Ed. Beatriz Castro Carvajal. Bogotá: Norma, 1996.

Delumeau, Jean. El miedo en occidente. Siglos XIV-XVIII. Madrid: Taurus, 1981.

Delumeau, Jean. La confesión y el perdón. Madrid: Alianza Universidad, 1992.

Díaz, Carmen. "El cuerpo: Ese objeto marcado por el exceso del otro". Desde el Jardin de Freud 3 (2003): 98-105.

Diccionario de la lengua castellana en que se explica el verdadero sentido de las voces, su naturaleza y calidad, con las frases o modos de hablar, los 


\section{FRONTERAS}

de la historia

Vol.12 / 2007

proverbios o refranes y otras cosas convenientes al uso de la lengua. 2 vol. Madrid: Gredos, 1969.

Duby, Georges. Damas del siglo XII: Eva y los sacerdotes. Madrid: Alianza, 1998.

—. Leonor de Aquitania y María Magdalena. Madrid: Alianza, 1996.

Durán, María Norma. "Ascesis, culpa y subjetividad. Un estudio de la vida de F. Sebastián de Aparicio escrita por F. Juan de Torquemada". Trabajo de grado de doctorado. Universidad Iberoamericana, 2004.

Echeverría, Bolívar. "La Compañía de Jesús y la primera modernidad de América Latina". Barrocos y modernos. Nuevos caminos en la investigación del Barroco Iberoamericano. Ed. Petra Schumm. Frankfurt; Madrid: Vervuert \& Iberoamericana, 1998.

Épiney, G. y E. Brunn. Mujeres trovadoras de Dios. Una tradición silenciada en la Europa Medieval. Barcelona: Gedisa, 1998.

Ferrús, Beatriz. "Heredar la Palabra: Vida, escritura y cuerpo en América Latina". Trabajo de grado de doctorado. Universidad de Valencia, 2005.

Foucault, Michel. Microfisica del poder. Madrid: La Piqueta, 1992.

Foz y Foz, Pilar. Mujer y educación en Colombia. Siglos XVI-XIX. Bogotá: Academia Colombiana de Historia, 1997.

Gélis, Jacques. "El cuerpo, la iglesia y lo sagrado". Del Renacimiento al Siglo de las Luces. Madrid: Taurus, 2005. Vol. 1 de Historia del Cuerpo. Dirs. Alain Corbin, Jacques Courtine, Georges Vigarello. Trad. Paloma Gómez. 3 vols. 2005.

Glantz, Margo. "El cuerpo monacal y sus vestiduras". Barrocos y modernos. Nuevos caminos en la investigación del Barroco Iberoamericano. Ed. Petra Schumm. Frankfurt-Madrid: Vervuert \& Iberoamericana, 1998.

-. Sor Juana Inés de la Cruz: ¿Hagiografia o autobiografia? México: Grijalbo, 1995.

Guattari, Félix. "Acerca de la producción de subjetividad". Caosmosis, Félix Guattari. Trad. Irene Ago. Buenos Aires: Manantial, 1996.

Heidegger, Martín. Estudios sobre mística medieval. Madrid: Siruela, 1997.

Ibsen, Kristine. Women's Spiritual Autobiography in Colonial Spanish America. Florida: The University Press of Florida, 1999.

Irigaray, Lucy. Spéculum de l'autre femme. París: Editions de Minuit, 1974. 
Jaramillo, Jaime. La sociedad neogranadina. Bogotá: Tercer Mundo; Uniandes, 1989. T.1 de Ensayos de historia social. 1989.

Klapisch, C. "La mujer y la familia". El hombre medieval. Ed. Jacques Le Goff Madrid: Alianza, 1987.

Kristeva, Julia. Semiótica. Trad. José Martín Arancibia. vol. 2. Madrid: Fundamentos, 1978.

Lacan, Jacques. El yo en la teoría de Freud y en la técnica psicoanalítica. Buenos Aires: Paidós, 1984. Lib. 2 de El Seminario. 10 vol. 1983-2006.

Lavrin, A. Sexualidad y matrimonio en la América Hispánica: Siglos XVI-XVIII. México: Grijalbo, 1991.

Lavrin, Asunción, comp. Las mujeres latinoamericanas. Perspectivas históricas. México: Fondo de Cultura Económica, 1985.

Le Goff, Jacques. El nacimiento del Purgatorio. Madrid: Taurus, 1989.

—, ed. El hombre medieval. Madrid: Alianza, 1987.

Lobrichon, Guy. La religion des laïcs en occident XI-XV siècles. París: Hachette, 1994.

Loyola, Ignacio de. Ejercicios espirituales. Madrid: Atlas, 1944.

Madrid, Alonso de. Arte para servir a Dios. Madrid: Biblioteca de Escritores Místicos Franciscanos, 1948.

Mendiola, Alfonso. "La inversión de lo pensable". Historia y Grafía 7 (1996).

Morales, Helí. "De tatuajes y garabatos: el síntoma de la escritura". Escritura y psicoanálisis. Coord. Helí Morales Asensio. México: Siglo XXI, 1986.

Moraña, Mabel, coord. Viaje al silencio, exploraciones en el discurso barroco. México: UNAM, 1998.

Mujica, Ramón. Rosa Limenis. Mística, politica e iconografía en torno a la patrona de América. Lima: IFEA; FCE; Banco Central de Reserva del Perú, 2001.

Muriel, J. Los recogimientos de mujeres. México: Universidad Autónoma de México, 1974.

Nasio, Juan David. Los gritos del cuerpo. Buenos Aires: Paidós, 1996.

Ortega, Santiago, ed. De la santidad a la perversión o de por qué no se cumplía la ley de Dios en la sociedad novohispana. México: Grijalbo, 1995.

Pastor, Marialba. Cuerpos sociales, cuerpos sacrificiales. México: Universidad Nacional Autónoma de México-Fondo de Cultura Económica, 2004. 


\section{FRONTERAS}

de la historia

Quevedo, María Piedad. "Un cuerpo para el espíritu. Mística en la Nueva Granada: El cuerpo, el gusto y el asco. 1680-1750”. Trabajo de grado de maestría. Pontificia Universidad Javeriana, 2005.

Robledo, Ángela Inés. Autobiografia de una monja venerable. Cali: Universidad del Valle, 1994.

Rochetta, Carlo. Hacia una teología de la corporeidad. Madrid: Paulinas, 1993.

Rodríguez-San Pedro, Luis y José Sánchez-Lora. Los siglos XVI-XVII, Cultura y vida cotidiana. Madrid: Síntesis, 2000.

Rosenthal, J., ed. Medieval Women and the Sources of Medieval History. Georgia: The University of Georgia Press, 1990.

Rubial, Antonio. La santidad controvertida. México: Fondo de Cultura Económica, 1999.

Sánchez Lora, José. Mujeres, conventos y formas de la religiosidad barroca. Madrid: Fundación Universitaria Española, 1988.

Siles del Valle, Juan Antonio. "Mística, erotismo, trasgresión y poesía". El cuerpo en los imaginarios. La Paz: Fundación Simón I. Patiño, 2003.

Soler, Colette. "El cuerpo en la enseñanza de Jaques Lacan". Traducciones. s.l.: s.e., 1998.

Stoichita, Víctor. El Ojo místico. Pintura y visión religiosa en el Siglo de Oro español. Madrid: Alianza, 1996.

Vega, Leonardo. Pecado y delito en la Colonia: La bestialidad como una forma de contravención sexual (1740-1808). Santa Fe de Bogotá: Instituto Colombiano de Cultura Hispánica, 1994.

Villari, Rosario, comp. El hombre barroco. Madrid: Alianza, 1992.

Walter, Caroline. "El cuerpo femenino y la práctica religiosa en la Baja Edad Media". Fragmentos para una historia del cuerpo humano. Vol. 1. Comp. Michel Feher. Madrid: Taurus, 1990.

Zumthor, Paul. La medida del mundo. Representación del espacio en la Edad Media. Madrid: Cátedra, 1994.

Zuleta, Pilar de. "La vida cotidiana en los conventos de mujeres". Historia de la vida cotidiana en Colombia. Ed. Beatriz Castro Carvajal. Bogotá: Norma, 1996. 426-27.

Fecha de recepción: $1^{\circ}$ de febrero de 2007.

Fecha de aprobación: 30 de julio de 2007. 